\title{
EKG-gyöngyszem: acut coronaria szindrómát utánzó sinuscsomó-betegség - az aVR-jel
}

\author{
Tomcsányi János dr. \\ Budai Irgalmasrendi Kórház, Kardiológiai Osztály, Budapest
}

\begin{abstract}
Az aVR-jel fő́törzs-, illetve súlyos háromér-betegségnek lehet az EKG-jele, de nem egyenlő a STEMI-vel, és nem szenzitív jele a coronariabetegségnek. Erre mutat példát a következő eset. Egy 89 éves nőbeteget mellkasi fájdalommal, pitvarfibrillációval és sok elvezetésre kiterjedő ST-depresszióval vettünk fel. Az aVR-elvezetésben azonban STeleváció volt. Az aVR-jelre való tekintettel urgens coronarographia történt, negatív eredménnyel. Késő́bb a sinusrhythmus helyreállt. A repolarizációs zavarok megszúntek a sinusrhythmus alatt. A monitorelvezetések váratlan hosszabb pauzákat mutattak, ami az EKG alapján változó SA-blokknak felelt meg. Mindezek alapján sinuscsomóbetegség állt a háttérben, amelyben a pitvarfibrilláció alatti repolarizációs zavar acut coronaria syndromát mimikázott. A beteg pacemakerbeültetés után orális antikoaguláns kezeléssel távozott otthonába.

Orv Hetil. 2020; 161(11): 434-436.
\end{abstract}

Kulcsszavak: acut coronaria syndroma, pitvarfibrilláció, ST-eleváció, sinuscsomó-betegség

\section{ECG pearl: sick sinus syndrome mimicking acute coronary syndrome - the aVR-sign}

The aVR-sign can indicate left main or multivessel coronary disease, but the sign is not STEMI eqvivalent and is not a sensitive sign for coronary disese. The following case is an example of this. An 89-year-old woman was admitted with chest pain, atrial fibrillation and multiple lead ST-segment depression but ST-segment elevation in lead aVR. The aVR-sign indicated urgent angiography with negative result. A spontaneous sinus conversion was observed with repolarization normalisation. Later the ECG demonstrated SA-blocks, and sinus arrest. Sick sinus syndrome was diagnosed and the patient was treated with pacemaker and oral anticoagulant.

Keywords: acute coronary syndrome, atrial fibrillation, ST-segment elevation, sick sinus syndrome

Tomcsányi J. [ECG pearl: sick sinus syndrome mimicking acute coronary syndrome - the aVR-sign]. Orv Hetil. 2020; 161(11): 434-436.

(Beérkezett: 2019. október 4.; elfogadva: 2019. november 17.)

\section{Rövidítések}

aVR = augmented vector right; aVR-STE = aVR-ST-eleváció; $\mathrm{COPD}=($ chronic obstructive pulmonary disease $)$ krónikus obstruktív tüdőbetegség; EKG = elektrokardiográfia; hs-troponin $=$ (high-sensitivity troponin $)$ magas érzékenységú troponin; $\mathrm{LAD}=$ (left artery descending) bal elülső leszálló coronaria; $\mathrm{PSVT}=$ paroxysmalis supraventricularis tachycardia; $\mathrm{SA}=$ sinoatrialis; STEMI = (ST-elevation myocardial infarction $)$ ST-elevációs myocardialis infarctus; TSH = (thyroid-stimulating hormone) pajzsmirigy-stimuláló hormon

\section{Esetismertetés}

A 89 éves nőbeteget sürgősséggel vették fel 2 órája tartó mellkasi fájdalom miatt. Anamnézisében 20 éve ismert hypertonia és 10 éve ismert COPD szerepelt. 70 évig dohányzott (napi 20 szál), de két éve abbahagyta, amikor az ízületi panaszokra szedett nemszteroid gyulladáscsökkentőktôl gyomorvérzése lett. Az EKG-n pitvarfibrillációs tachyarrhythmia mellett kiterjedt ST-depressziókat és az aVR-elvezetésben ST-elevációt láttak a sürgősségi 


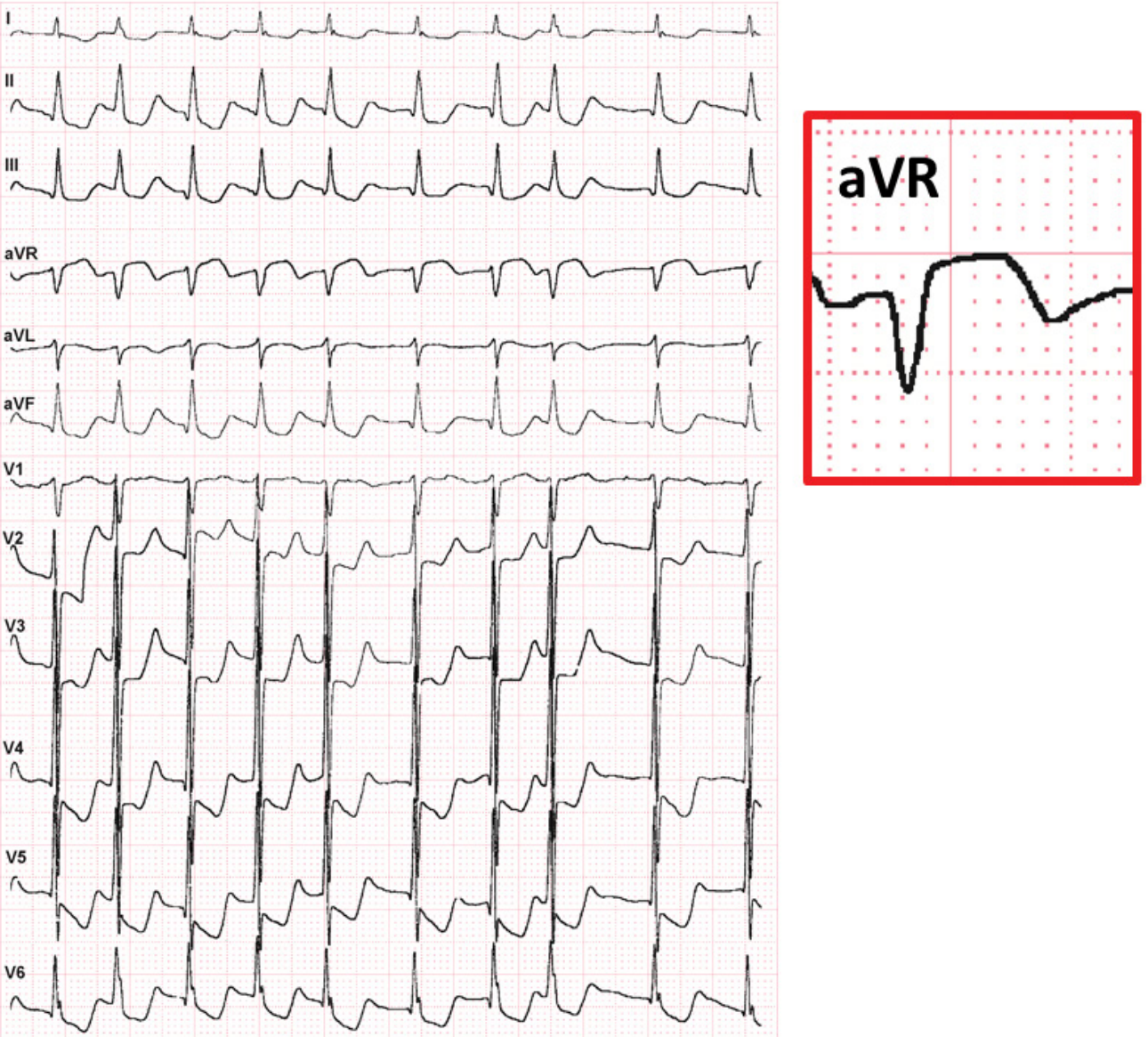

1. ábra

| 126/min átlagfrekvenciájú tachyarrhythmia. Kiterjedt deszcendáló ST-depresszió, az aVR-elvezetésben pedig l mm-es ST-eleváció látható

osztályon (1. ábra). Ezért urgens coronarographiára küldték. Átvételekor a sinusrhythmus már helyreállt, az ST-deviációk megszűntek (2. ábra). A coronarographián érfal-egyenetlenségeken kívül egyéb eltérés nem volt. Laborleleteiben a TSH normális volt, kreatin-kinázemelkedés nem volt, a hs-troponin stacioner emelkedést mutatott. Az echocardiographia fali mozgászavart nem igazolt. A monitorozás során váratlan hosszabb pauzák jelentkeztek, amit a 12 elvezetéses EKG is igazolt (3. ábra). A pauzákat a változó arányú SA-blokkok idézték elő, tovább erősítve azt a gyanút, hogy a pitvarfibrillációt sinuscsomó-betegség okozza. A beteg pacemakerimplantációban részesült, és a gyomorvédő terápia melletti antikoaguláns beállítása után otthonába távozott.

\section{Megbeszélés}

A 12 elvezetéses EKG elemzésekor az elmúlt időszakig csak 11 elvezetést vettünk figyelembe. Gorgels és mtsai [1] voltak azok, akik a 2000-es évek elején az aVR-elvezetés jelentőségére felhívták a figyelmet. Azóta több publikáció is megjelent, amelyek az aVR-elvezetésben jelentkező ST-eleváció fötörzsbetegség, illetve proximalis, gravis háromér-betegség esetén való fennállásának diagnosztikus szerepét tárgyalták [2]. Olyannyira, hogy már a 2013. évi amerikai ST-elevációs ajánlásba is belekerült: amennyiben a kiterjedt ST-depressziók mellett aVR-STE van, akkor az vagy fötörzs-, vagy proximalis LAD-betegséget jelent [3]. Ugyanakkor napjainkban megjelent publikációk arra hívják fel a figyelmet, hogy az ún. aVR-jel nem egyenlő az azonnali intervenciót igénylő gravis coronariabetegség acut megjelenési formájával $[4,5]$. Számos egyéb betegség is tud ST-elevációt okozni az aVR-elvezetésben. Talányos, hogy egyes supraventricularis rhythmuszavarok miként lehetnek az okai kiterjedt repolarizációs zavaroknak. De ismert, hogy mind a PSVT-k, mind a pitvarfibrillációk önmagukban okozhatnak repolarizációs zavarokat, amelyek megszúnnek, ha a rhythmuszavar megszűnik. Ez történt a jelen esetben is. Mivel azonban az aVR-elvezetésben jelentkező ST-eleváció és a többi elvezetésben kiterjedt ST-depressziók vagy súlyos fötörzsbetegségre, vagy súlyos háromér-betegségre utalhatnak, urgens coronarographia történt, negatív eredménnyel. Ez is alátámasztja azt a tényt, hogy a pitvarfibrilláció repolarizációs zavart indukálhat.

Az eset legfontosabb üzenete, hogy az EKG-n látható aVR-ST-eleváció önmagában nem jelent sem feltétlen coronariabetegséget, sem azonnali coronariaintervenciós indikációt. 


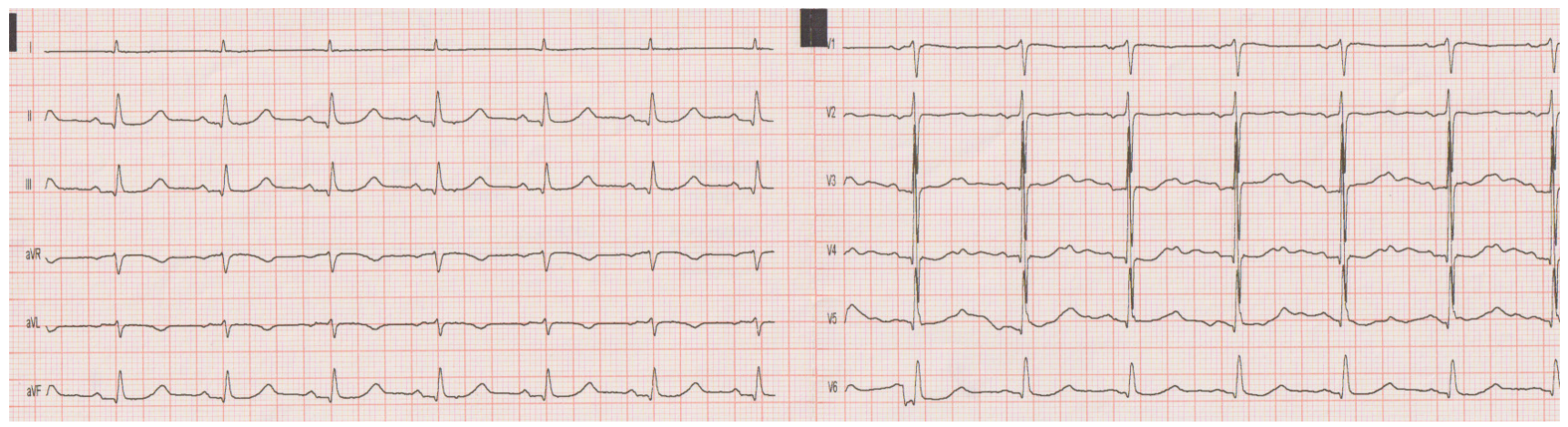

2. ábra | Sinusrhythmus, normális PR-intervallum és normális depolarizáció és repolarizáció

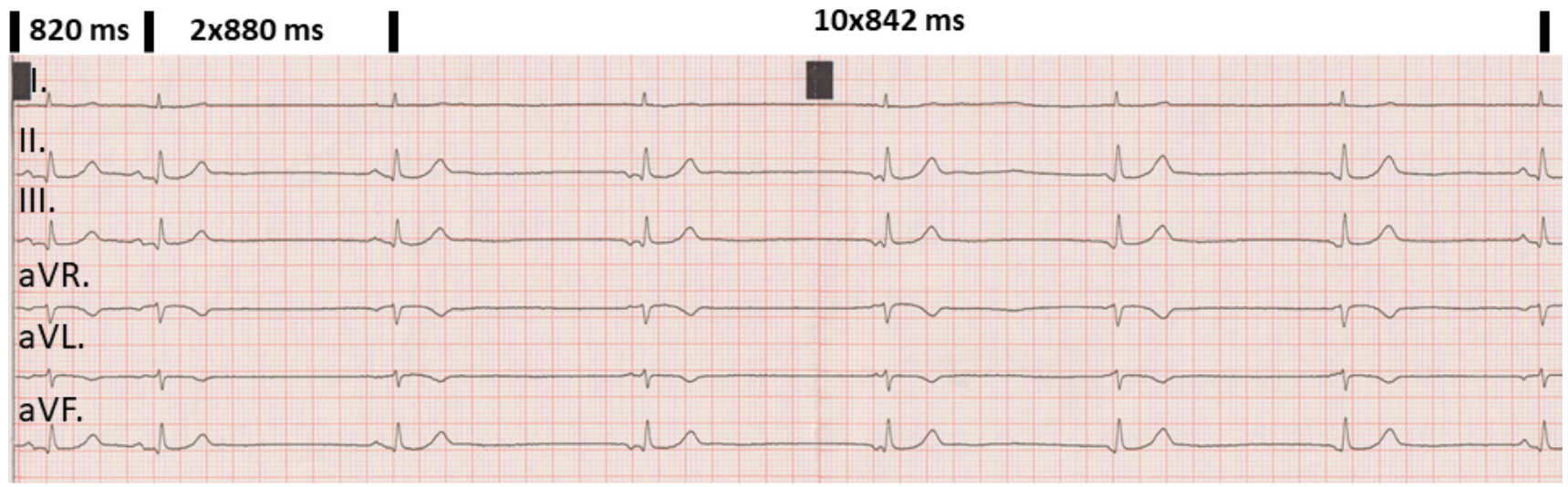

3. ábra

Sinusrhythmust $(820 \mathrm{~ms})$ egy kettő-egyes SA-blokk követ $(2 \times 880 \mathrm{~ms})$, majd egy hosszú sinusleállás alatt alsó pitvari junctionalis rhythmus van. A sinuspauza egy tíz-egyes SA-blokknak felel meg $(10 \times 842 \mathrm{~ms})$

Anyagi támogatás: A közlemény megírása anyagi támogatásban nem részesült.

A szerző a cikk végleges változatát elolvasta és jóváhagyta.

Érdekeltségek: A szerzőnek nincsenek érdekeltségei.

\section{Irodalom}

[1] Gorgels AP, Engelen DJ, Wellens HJ. Lead aVR, a mostly ignored but very valuable lead in clinical electrocardiography. J Am Coll Cardiol. 2001; 38: 1355-1356.

[2] Kosuge M, Kimura K, Ishikawa T, et al. Predictors of left main or three-vessel disease in patients who have acute coronary syndromes with non-ST-segment elevation. Am J Cardiol. 2005; 95: 1366-1369.
[3] O'Gara PT, Kushner FG, Ascheim DD, et al. 2013 ACCF/AHA guideline for the management of ST-elevation myocardial infarction: a report of the American College of Cardiology Foundation/American Heart Association Task Force on Practice Guidelines. Circulation 2013; 127: e362-e425.

[4] Harhash AA, Huang JJ, Reddy S, et al. aVR ST segment elevation: acute STEMI or NOT? Incidence of an acute coronary occlusion. Am J Med. 2019; 132: 622-630.

[5] Gibbs M, Leedekerken JB, Littmann L. Evolution of our understanding of the aVR sign. J Electrocardiol. 2019; 56: 121-124.

(Tomcsányi János dr., Budapest, Árpád fejedelem u. 7., 1027 e-mail: tomcsanyij@gmail.com) 